Jurnal Interpretasi Hukum | ISSN: 2746-5047

Vol. 2, No. 3-Desember 2021, Hal. 641-645| Tersedia online di https://www.ejournal.warmadewa.ac.id/index.php/juinhum DOI: https://doi.org/10.22225/juinhum.2.3.4164.641-645

\title{
PERLINDUNGAN HUKUM BAGI PEMILIK KARTU ELEKTRONIK DALAM TRANSAKSI E-COMMERCE
}

\author{
Putu Widhiatmika Coryka, I Nyoman Putu Budiartha, Ni Made Puspasutari Ujianti \\ Fakultas Hukum, Universitas Warmadewa, Denpasar-Bali, Indonesia \\ widhiatmikacoryka@gmail.com, budiarthaputu59@gmail.com, puspasutariujianti@gmail.com
}

\begin{abstract}
Abstrak
Kontrak elektronik adalah kontrak yang dilakukan oleh para pihak melalui media elektronik, masing-masing para pihak ketika melakukan negosiasi tidak perlu melakukan pertemuan langsung melainkan menggunakan media elektronik seperti email. Saat ini kontrak elektronik telah mendapatkan keabsahan dan perlindungan oleh UU Nomor 11 Tahun 2008 tentang Informasi dan Transaksi Elektronik. Penelitian ini bertujuan untuk mengkaji keabsahan yang sama dengan kontrak tertulis pada perjanjian kepemilikan kartu kredit dan mengungkapkan perlindungan hukum bagi pemilik kartu kredit dalam melakukan transaksi E-commerce. Penelitian ini dilakukan dengan menggunakan penelitian hukum Normatif. Adapun sumber bahan hukum adalah bahan hukum primer yaitu bersumber dari Perundang-undangan dan sumber bahan hukum sekunder diambil dari literatur-literatur yang relevan dengan masalah yang dikaji. Setelah data penelitian terkumpul, selanjutnya diolah dan dianalisis dengan cara kualitatif deskriptif. Hasil penelitian menunjukkan bahwa perlindungan hukum yang diberikan Pasal 26 Undang-undang Nomor 8 Tahun 1999 memberikan perlindungan bagi konsumen dengan mewajibkan pelaku usaha yang memperdagangkan jasa, untuk memenuhi jaminan dan atau atau garansi yang disepakati. Kontrak elektronik merupakan bukti yang sah apabila dihadirkan sebagai bukti pada meja persidangan berdasarkan pasal 5 Undang-undang Nomor 11 Tahun 2008 tentang Informasi dan Transaksi Elektronik.
\end{abstract}

Kata Kunci: Kontrak Elektronik, Kartu Kredit, Perlindungan Hukum

\begin{abstract}
An electronic contract is a contract made by the parties through electronic media, each party when negotiating does not need to have a face-to-face meeting but uses electronic media such as email. Currently, electronic contracts have received legitimacy and protection by Law Number 11 of 2008 concerning Electronic Information and Transactions. This study aims to examine the validity of the same as written contracts on credit card ownership agreements and to reveal legal protection for credit card owners in conducting E-commerce transactions. This research was conducted using normative legal research. The sources of legal materials are primary legal materials, which are sourced from legislation and secondary sources of legal materials are tak en from relevant literatures with the issues studied. After the research data has been collected, it is then processed and analyzed in a descriptive qualitative way. The results of the study indicate that the legal protection provided by Article 26 of Law Number 8 of 1999 provides protection for consumers by requiring business actors who trade services to fulfill agreed guarantees and or guarantees. An electronic contract is valid evidence if it is presented as evidence at the court table based on article 5 of Law Number 11 of 2008 concerning Electronic Information and Transactions.
\end{abstract}

Keywords: Electronic Contracts, Credit Cards, Legal Protection

\section{PENDAHULUAN}

Perkembangan zaman saat ini dibeberapa negara di dunia selalu diikuti globalisasi yang mendorong kemajuan di bidang ekonomi, memudahkan sistem perdagangan, dahulu setiap akitivitas perdagangan lebih cenderung menggunakan sistem konvensional, yaitu dengan berinteraksi secara langsung antara pelaku bisnis atau pedagang dengan konsumen (Hendro Setyo Wahyudi, 2014). Namun seiring berkembangnya globalisasi dan kemajuan teknologi yang terjadi saat ini, membuat perubahan terhadap cara perdagangan yang dilakukan secara konvensional yang dialihkan dalam bentuk online menggunakan sarana elektronik. Istilah transaksi elektronik atau yang lebih dikenal dengan $E$ Commerce memberikan banyak kemudahan terhadap para pihak yang terlibat dalam suatu kegiatan bisnis, mulai dari kontrak bisnis yang dilakukan secara elektronik hingga metode pembayaran yang dilakukan secara elektronik (Ummah, 2017). 
Pada saat ini, transaksi secara elektronik banyak diminati oleh berbagai kalangan masyarakat di seluruh dunia dikarenakan sistemnya yang sangat memberikan kemudahan terhadap sistem perdagangannya dikarenakan antara pelaku usaha dan konsumen tidak perlu melakukan pertemuan yang digantikan dengan cara virtual melalui berbagai aplikasi pertemuan yang dapat dilakukan secara tatap muka menggunakan media internet. Pada jaman era globalisasi ini, terdapat berbagai media online yang berkecimpung dalam kegiatan transaksi elektronik atau transaksi digital, hal tersebut memberikan kemudahan terhadap sistem perdagangan yang dilakukan dikarenakan memiliki cakupan yang sangat luas, mengingat transaksi elektronik ini bisa dilakukan oleh para pelaku usaha dan konsumen di seluruh dunia tanpa harus bersusah payah untuk meluangkan waktunya untuk dapat bertemu secara langsung (Yuliana, 2000).

Meskipun pada saat melakukan kesepakatan bisnis yang bersifat virtual hal tersebut dapat dikategorikan sebagai tindakan atau perbuatan hukum yang nyata. Secara hukum ruang dalam melakukan transaksi bisnis sangat sulit untuk dilacak keberadaan pihak tersebut sehingga dalam melakukan kontrak bisnis secara elektronik atau digital sangat diperlukan kehati-hatian ketika hendak mengadakan kontrak bisnis, dikarenakan dalam melakukan kontrak bisnis ini memiliki risiko yang sangat tinggi (Nugroho, 2016). Apabila dicermati dari pengertian transaksi elektronik itu sendiri, yang dimaksud dengan transaksi elektronik adalah metode transaksi yang dilakukan tanpa melakukan pertemuan secara langsung ketika melakukan suatu perikatan, selain itu bentuk kontrak bisnis yang dituangkan dalam bentuk transaksi elektronik merupakan bentuk kontrak yang dituangkan dalam bentuk konvensional pada umumnya, yang membedakan dari transaksi elektronik dengan transaksi secara konvensional adalah terletak pada media penuangan isi kontrak yang di lakukan melalui surat elektronik, sedangkan transaksi elektronik isi dari kontrak tersebut dituangkan secara langsung di atas kertas dengan melakukan pertemuan langsung antara para pihak yang terlibat dalam transaksi elektronik atau yang biasa disebut dengan E-commerce (Ali, 2010)

Pada jaman era globalisasi ini terdapat berbagai media online yang berkecimpung dalam kegiatan transaksi elektronik atau transaksi digital, hal tersebut memberikan kemudahan terhadap sistem perdagangan yang dilakukan dikarenakan memiliki cakupan yang sangat luas, mengingat transaksi elektronik ini bisa dilakukan oleh para pelaku usaha dan konsumen di seluruh dunia tanpa harus bersusah payah untuk meluangkan waktunya untuk dapat bertemu secara langsung. Pada saat ini transaksi secara elektronik banyak diminati oleh berbagai kalangan masyarakat di seluruh dunia dikarenakan sistemnya yang sangat memberikan kemudahan terhadap sistem perdagangannya dikarenakan antara pelaku usaha dan konsumen tidak perlu melakukan pertemuan yang digantikan dengan cara virtual melalui berbagai aplikasi pertemuan yang dapat dilakukan secara tatap muka menggunakan media internet. Secara hukum ruang dalam melakukan transaksi bisnis sangat sulit untuk dilacak keberadaan pihak tersebut sehingga dalam melakukan kontrak bisnis secara elektronik dan/atau digital sangat diperlukan kehati-hatian ketika hendak mengadakan kontrak bisnis, dikarenakan dalam melakukan kontrak bisnis ini memiliki risiko yang sangat tinggi (Nasution, 1995).

Saat ini banyak kemudahan metode transaksi yang ditawarkan pada transaksi elektronik $E$ commerce diantaranya adalah dengan menggunakan kartu kredit atau yang biasa disebut dengan kartu debit, kartu kredit merupakan metode pembayaran yang dilakukan tanpa harus menggunakan pembayaran secara manual menggunakan uang, namun hanya menggunakan debit card atau yang biasa disebut dengan kartu kredit, kartu kredit dapat dimiliki oleh setiap orang dengan kepasitas pembayaran yang berbeda-beda terhadap setiap pemegang kartu krdit, dalam hal ini adanya limit pembayaran yang dapat dilakukan oleh setiap orang ketika melakukan transaksi baik secara konvensional maupun online.

Transaksi elektronik atau yang biasa disebut dengan e-commerce apabila dilihat melalui dua sisi, tentunya memiliki dampak positif dan dampak negatif dari transaksi elektronik itu sendiri, apabila kita lihat transaksi elektronik melalui sisi positif, maka dapat dilihat bahwa transaksi elektronik atau E-commerce sangat banyak memiliki manfaat dan kegunaan dalam bidang transaksi, yakni mempermudah para pihak dalam menyusun substansi kontrak elektronik yang akan disepakati dan menghemat waktu dalam melakukan negosiasi (Yuliana, 2000). Dampak negatif dari transaksi elektronik atau yang biasa disebut dengan E-commerce salah satunya adalah para pihak dalam melakukan negosiasi tidak melakukan pertemuan secara langsung untuk dapat membahas kemungkinan-kemungkinan yang akan terjadi dalam kerjasama yang dilakukan oleh para pihak 
(Rongiyati, 2019). Kotrak elektronik memiliki peranan yang sangat penting dalam metode transaksi $e$ commerce ini, karena dalam melakukan suatu perikatan dengan rekan bisnis, seseorang tidak perlu melakukan pertemuan secara langsung dengan pertemuan yang dilakukan secara tatap muka, cukup melakukan negosiasi yang dilakukan secara daring atau online. Para pihak tidak leluasa untuk menentukan isi kontrak yang akan disepakati oleh para pihak, selain itu di Indonesia transaksi elektronik dalam Kitab Undang-undang Hukum Perdata tidak disebutkan bahwa bentuk perikatan atau kerjasama yang dilakukan oleh para pihak dapat dilakukan dalam bentuk elektronik, sehingga pemerintah menerbitkan UU ITE sebagai dasar hukum untuk mengatur mengenai transaksi elektronik yang terjadi seiring perkembangan jaman apabila dikemudian hari menuai suatu permasalahan diantara para pihak (Nasution, 1995).

Berdasarkan penjabaran permasalahan yang telah dipaparkan dari penelitian sebelumnya maka penelitian ini melanjutkan penelitian sebelumnya yaitu mengkaji keabsahan yang sama dengan kontrak tertulis pada perjanjian kepemilikan kartu kredit dan mengungkapkan perlindungan hukum bagi pemilik kartu kredit dalam melakukan transaksi E-commerce.

\section{METODE PENELITIAN}

Penelitian yang digunakan adalah penelitian hukum normative yaitu penelitian yang menggunakan pengkajian masalah melalui pendekatan peraturan perundang-undangan yang berlaku atau hukum positif di Indonesia, sehingga pengkajian masalah melalui pendekatan undang-undang menjadi sumber bahan hukum utama dalam penulisan jurnal skripsi ini (Hartono, 1991). Selanjutnya sumber bahan hukum sekunder yang digunakan dalam pengkajian jurnal ilmiah adalah dengan menggunakan pendekatan pengkajian melalui buku-buku akademik sebagai referensi utama dalam memecahkan masalah-masalah yang dihadapi, sedangkan sumber bahan hukum tersier yag digunakan dalam pemecahan masalah adalah dengan menggunakan kamus-kamus hukum, jurnal yang memiliki kaitan erat dengan permasalahan yang sedang diteliti. Teknik pengumpulan data dengan menggunakan teknik studi pustaka guna membantu memecahkan masalah-masalah yang dihadapi ketika melakukan penelitian, langkah-langkah yag dilakukan ketika mengumpulkan sumber bahan hukum dalam penelitian ini yakni terlebih dahulu mencari sumber bahan hukum primer meliputi peraturan perundang-undangan, kamus penunjang, selanjutnya melakukan filterisasi dalam memilah-milah sumber bahan hukum yang sudah terkumpul tadi, apabila sudah terkumpul maka digunakan teknik elaborasi yakni menggabungkan sumber bahan hukum primer, sekunder dan tersier tadi dengan logika deduktif dan induktif (Bambang Sunggono, 2011).

\section{HASIL DAN PEMBAHASAN}

\section{Keabsahan Kontrak Tertulis pada Perjanjian Kepemilikan Kartu Kredit}

Dalam menghadapi era teknologi informasi yang semakin cepat tanpa dibatasi waktu dan wilayah negara, hukum di Indonesia sangat jauh tertinggal. Banyak permasalahan-pemasalahan yang belum terpecahkan melalui instrumen hukum ini. Pengembangan sektor hukum diharapkan mampu memberikan kontribusi terhadap percepatan pembangunan perekonomian. Padahal kondisi umum di Indonesia belum mendukung kesiapan Indonesia dalam menghadapi persaingan global. Saat ini internet merupakan penyumbang angka kejahatan yang sangat signifinak, kemunculan kejahatan yang terjadi di internet sangat beragam jenis, mulai dari penipuan, penyebaran berita bohong dan berbagai kejahatan lainnya, tentunya hal tersebut sangat perlu mendapatkan perhatian khusus dari pemerintah guna menanggulangi hal tersebut, saat ini kejahatan yang terjadi di dunia internet sering disebut sebagai cyber crime atau kejahatan yang dilakukan melalui dunia maya, kejahatan di internet dapat dilakukan oleh berbagai orang di seluruh dunia. Cybercrime atau kejahatan yang terjadi di dunia maya merupakan kejahatan yang tergolong baru apabila dibandingkan dengan kejahatan yang tidak dilakukan pada dunia maya, kejahatan dunia maya makin berkembang pesat saat ini, seiring perkembangan teknologi internet yang terjadi saat ini (M. Hadjon Philipus, 198712-15).

Indonesia merupakan suatu Negara Hukum yang mana segala tingkah laku atau perbuatan yang dilakukan oleh manusia diatur oleh hukum. Hukum harus sungguh-sungguh difungsikan agar pembangunan ekonomi benar-benar berjalan sesuai dengan garis kebijaksanaan yang diamanatkan oleh Undang-undang Dasar 1945. Hukum seharusnya berdiri di depan pembangunan, sebab jika tidak demikian persoalan ketidakpastian hukum akan selalu muncul mengiringi perkembangan 
perekonomian (Atmadja \& Budiartha, 2018). Pengaturan mengenai transaksi elektronik di Indonesia secara khusus telah diatur di dalam Undang-undang Nomor 11 tahun 2008 tentang Informasi dan Transaksi Elektronik khususnya di dalam Pasal 20 ayat (2) UU No.11 Tahun 2008 tentang Transaksi Elektronik, dalam pasal ini disebutkan bahwa setiap transaksi elektronik yang dilakukan oleh para pihak haruslah dilakukan pernyataan penerimaan secara elektronik, selain itu di dalam Pasal 14571458 Kitab Undang-Undang Hukum Perdata dijelaskan bahwa setiap transaksi elektronik berlaku sah bagi setiap pihak yang membuatnya. Dalam hal terjadinya sengketa bisnis yang terjadi antara para pihak, guna memberikan perlindungan hukum terhadap para pihak yang bersengketa maka setiap bukti transaksi elektronik merupakan bukti yang sah sebagaimana diatur di dalam 5 ayat (1), ayat (2) dan ayat (3) Undang-undang No. 11 Tahun 2008 tentang Informasi dan Transaksi Elektronik.

Kontrak elektronik merupakan perjanjian yang sah yang berlaku bagi para pihak yang membuatnya, sebagaimana menurut asas kebebasan berkontrak, walaupun media yang digunakan adalah surat elektronik atau email, tidak dapat dipungkiri bahwa keabsahan dari kontrak elektronik berlaku sebagai undang-undang bagi para pihak yang membuatnya sebagaimana diatur didalam Pasal 5 ayat (1), ayat (2) dan ayat (3) Undang-undang No. 11 Tahun 2008 tentang Informasi dan transaksi elektronik.

\section{Perlindungan Hukum bagi Pemilik Kartu Kredit dalam Melakukan Transaksi E-Commerce}

Perlindungan hukum terhadap pemilik kartu kredit yang melakukan kegiatan perdagangan dengan menggunakan sistem transaksi elektronik telah diatur dalam pasal 5 ayat (1) Undang-undang No. 11 Tahun 2008 tentang Informasi dan Transaksi Elektronik, dimana dalam pasal 5 ayat (1) UU ITE menentukan bahwa setiap dokumen elektronik dan/atau cetakannya merupakan suatu bukti yang sah, dalam hal perlindungan hukum bagi para pihak dalam melakukan kontrak secara elektronik (Hadjon, 1987).

Dalam hal pengaturan perikatan bisnis di antara para pihak juga diatur di dalam Kitab Undangundang Hukum Perdata pasal 1320 dan Pasal 1457-1458 KUH Perdata, namun saat ini pemerintah dalam hal melakukan penegakan hukum pada transaksi elektronik telah diterbitkan aturan khusus yakni Undang-undang No. 8 Tahun 2011 tentang Informasi dan Transaksi Elektronik, apabila dalam melakukan kontrak dengan menggunakan sistem transaksi elektronik terjadi penipuan yang dilakukan oleh salah satu pihak maka dalam hal ini terjadi norma konflik antara Undang-undang No. 8 Tahun 2011 tentang Informasi dan Transaksi Elektronik dengan Kitab Undang-undang Hukum Pidana, Sehingga dalam memecahkan masalah norma konflik ini diberlakukan asas preferensi Lex Specialis Derogat Legi Generalis yakni ketentuan yang umum dikesampingkan untuk kepentingan peraturan yang khusus, sehingga dalam hal tersebut ketentuan yang terdapat di dalam UU No. 11 Tahun 2008 tentang Informasi dan Transaksi Elektronik lebih diutamakan daripada ketentuan yang terdapat di dalam Kitab Undang-undang Hukum Pidana yang sama-sama mengatur mengenai sanksi pertanggungjawaban pidana terhadap pelaku penipuan tersebut.

Berdasarkan hal tersebut perlindungan terhadap para pihak yang melakukan kontrak bisnis dengan menggunakan sistem transaksi elektronik dengan menggunakan kartu kredit mendapatkan perlindungan hukum secara preventif berupa diakuinya dokumen elektronik sebagai alat bukti yang sah sebagaimana diatur di dalam Pasal 5 Undang-undang No. 8 Tahun 2011 tentang Informasi dan Transaksi Elektronik, selain itu apabila terjadi penipuan maupun penggelapan yang dilakukan oleh salah satu pihak yang melakukan kontrak bisnis dengan menggunakan sistem transaksi elektronik mendapatkan perlindungan hukum berdasarkan pasal 45 Undang-undang No. 8 Tahun 2011 tentang Informasi dan Transaksi Elektronik. Berdasarkan uraian diatas perlindungan hukum terhadap pemegang kartu kredit dalam melakukan transaksi elektronik dilindungi oleh UU ITE apabila dikemudian hari terjadi permasalahan yang mengharuskan diselesaikan melalui meja hijau, bukti elektronik merupakan bukti yang sah.

\section{SIMPULAN DAN SARAN}

1. Simpulan

Berdasarkan pemaparan data dan analisis data, dapat disimpulkan kontrak elektronik merupakan perjanjian yang sah yang berlaku bagi para pihak yang membuatnya, sebagaimana menurut asas kebebasan berkontrak, walaupun media yang digunakan adalah surat elektronik atau email, tidak 
dapat dipungkiri bahwa keabsahan dari kontrak elektronik berlaku sebagai undang-undang bagi para pihak yang membuatnya sebagaimana diatur didalam Pasal 5 ayat (1), ayat (2) dan ayat (3) Undangundang No. 11 Tahun 2008 tentang Informasi dan transaksi elektronik. Perlindungan hukum secara preventif berupa diakuinya dokumen elektronik sebagai alat bukti yang sah sebagaimana diatur di dalam Pasal 5 Undang-undang No. 8 Tahun 2011 tentang Informasi dan Transaksi Elektronik, selain itu apabila terjadi penipuan maupun penggelapan yang dilakukan oleh salah satu pihak yang melakukan kontrak bisnis dengan menggunakan sistem transaksi elektronik mendapatkan perlindungan hukum berdasarkan pasal 45 Undang-undang No. 8 Tahun 2011 tentang Informasi dan Transaksi Elektronik.

\section{Saran}

Berdasarkan simpulan penelitian di atas, peneliti memberikan saran yaitu pemerintah, harus menyesuaikan perkembangan kejahatan cyber crime yang terjadi pada perkembangan zaman saat ini, agar menyesuaikan perkembangan peraturan Perundang-undangan terhadap perkembangan kejahatan pada pemegang kartu kredit dalam transaksi elektronik atau E-commerce. Kepada masyarakat yang sering mengalami kejahatan cyber crime terutama ketika melakukan transaksi elektronik menggunakan kartu kredit untuk sesegera mungkin melaporkan kejahatan tersebut kepada pihak berwajib dikarenakan kejahatan yang terjadi di dunia internet harus dilakukan secepat mungkin agar tidak banyak masyarakat yang menjadi korban.

\section{DAFTAR PUSTAKA}

Ali, M. (2010). Pencemaran Nama Baik Melalui Sarana Informasi dan Transaksi Elektronik (Kajian Putusan MK No. 2/PUU-VII/2009). Jurnal Konstitusi, 7(6), 119-146.

Atmadja, I. D. G., \& Budiartha, I. N. P. (2018). Teori-teori Hukum. Setara Press: Malang.

Bambang Sunggono. (2011). Metedologi Penelitian Hukum

Hadjon, P. M. (1987). Perlindungan Hukum Bagi Rakyat Indonesia. PT. Bina llmu. Surabaya.

Hartono, S. (1991). Politik Hukum Menuju Satu Sistem HukumnNasional. Bandung. Alumni.

Hendro Setyo Wahyudi, M. P. S. (2014). Teknologi dan Kehidupan Masyarakat. Jurnal Analisa Sosiologi, 3(1), 13-24.

Nasution, A. Z. (1995). Konsumen dan Hukum. Pustaka Sinar Harapan.

Nugroho, K. P. D. S. (2016). Aktualisasi Peran Pemimpin Nasional yang Visioner dapat Mengembangkan Pariwisata Kombes. Kajian Lemhannas RI, 27(September), 25.

Rongiyati, S. (2019). Pelindungan Konsumen dalam Transaksi Dagang Melalui Sistem Elektronik (Consumer Protection in E-Commerce). Negara Hukum, 10(1), 1-25.

Ummah, S. R. (2017). Pornografi Ditinjau dari Hukum Positif dan Hukum Pidana Islam. Jurnal Pemikiran Dan Pembaharuan Hukum Islam, 2(2), 26-35.

Yuliana, O. Y. (2000). Penggunaan Teknologi Internet dalam Bisnis. Jurnal Akuntansi Dan Keuangan, 2(1), 36-52. 